\title{
Type II collagen antibody response is enriched in the synovial fluid of rheumatoid joints and directed to the same major epitopes as in collagen induced arthritis in primates and mice
}

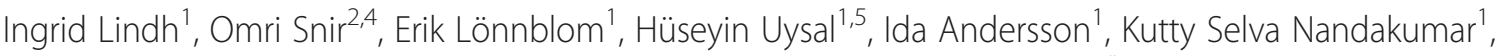 \\ Michel Vierboom ${ }^{3}$, Bert 't Hart', Vivianne Malmström² and Rikard Holmdahl ${ }^{3 *}$
}

\begin{abstract}
Introduction: Antibodies towards type II collagen (CII) are detected in patients with rheumatoid arthritis (RA) and in non-human primates and rodents with collagen induced arthritis (CIA). We have previously shown that antibodies specific for several Cll-epitopes are pathogenic using monoclonal antibodies from arthritic mice, although the role of different anti-Cll epitopes has not been investigated in detail in other species. We therefore performed an inter-species comparative study of the autoantibody response to CII in patients with RA versus monkeys and mice with CIA.

Methods: Analysis of the full epitope repertoire along the disease course of CIA was performed using a library of CII triple-helical peptides. The antibody responses to the major Cll epitopes were analyzed in sera and synovial fluid from RA patients, and in sera from rhesus monkeys (Macaca mulatta), common marmosets (Callithrix jacchus) and mice.

Results: Many Cll epitopes including the major C1, U1, and J1 were associated with established CIA and arginine residues played an important role in the anti-Cll antibody interactions. The major epitopes were also recognized in RA patients, both in sera and even more pronounced in synovial fluid: $77 \%$ of the patients had antibodies to the U1 epitope. The anti-Cll immune response was not restricted to the anti-citrulline protein antibodies (ACPA) positive RA group.

Conclusion: Cll conformational dependent antibody responses are common in RA and are likely to originate from rheumatoid joints but did not show a correlation with ACPA response. Importantly, the fine specificity of the anti-Cll response is similar with CIA in monkeys and rodents where the recognized epitopes are conserved and have a major pathogenic role. Thus, anti-Cll antibodies may both contribute to, as well as be the consequence of, local joint inflammation.
\end{abstract}

\section{Introduction}

Rheumatoid arthritis (RA) is an autoimmune, chronic inflammatory disorder affecting peripheral joints. RA is a complex disorder believed to consist of different pathogenetic mechanisms that may lead to common final pathways and shared clinical signs and symptoms. Recent progress has strengthened the view that a pathogenic process leading to RA starts many years before the

\footnotetext{
* Correspondence: Rikard.Holmdahl@ki.se

${ }^{1}$ Department of Medical Biochemistry and Biophysics, Section for Medical Inflammation Research, Karolinska Institutet, SE-171 77 Stockholm, Sweden Full list of author information is available at the end of the article
}

clinical onset. Individuals with a genetic predisposition, mainly based on certain MHC class II alleles, develop an antibody response to citrullinated proteins (anti-citrullinated protein antibodies (ACPA)) and to IgG (rheumatoid factors) combined with a raised systemic inflammatory response. Many years later the joints are affected. During the pre-RA period the autoantibody responses, including ACPA, is increased in titers and spreads in epitope specificity [1] and that antibodies to cartilage can be measured around clinical onset [2-4], where one of the autoantibody targets is collagen type II (CII). Over the years there has 
been a large discrepancy in the rate of the CII-specific response, ranging from a few percent up to $50 \%[3,4]$. Also unclear is whether the low titers can be of pathogenic or regulatory relevance. These variable results are probably due to technical artifacts due to the usage of solid-phase assays with crudely purified matrix protein.

Immunization of $\mathrm{CII}$ in animals gives rise to significant titers of autoantibodies to CII. Three CII-specific monoclonal antibodies (CII-C1, UL-1, and M2139) have been raised and characterized in detail by the molecular interaction with their target molecule [5-8], binding in vivo [9], and their pathogenic and regulatory importance [10]. It would therefore be of value to directly compare human antibody specificities with the specificity of autoantibodies in animals and also to develop assays that are not dependent on collagen prepared from tissue complexed with not very well defined matrix molecules, and instead use synthetic and recombinant triple-helical CII peptides containing identified epitopes known to be exposed and recognized by antibodies in vivo. The purpose of this study was thus to investigate the epitope repertoire of the major CII epitopes and to analyze these not only in RA but also in a comparative way in other species; that is, in monkeys and mice with collagen-induced arthritis (CIA).

\section{Materials and methods}

\section{Rheumatoid arthritis patients and healthy subjects}

Serum and synovial fluid (SF) samples were collected from a previously described patient cohort [11] with established RA (290 patients, mean age 55, age range 21 to $86,82 \%$ female) according to the American College of Rheumatology criteria [12]. For serum analysis of the $\mathrm{C} 1$ epitope, an additional 124 patients were included, giving a total of 414 patients (mean age 59, age range 21 to $100,80 \%$ female). All patients attended the Rheumatology Clinic at the Karolinska University Hospital, Sweden, and were included based on a clinical need for withdrawing SF from knee effusions. Serum sampling was performed in parallel. One hundred serum samples from healthy subjects (mean age 54 , range 24 to $82,81 \%$ female) were also analyzed and served as controls in this study. The ethical review board of the Karolinska University Hospital (Regionala Etikprövningsnämnden Stockholm) approved this study, and all subjects gave informed consent.

\section{Nonhuman primates and mice}

The Biomedical Primate Research Centre in Rijswijk, the Netherlands supplied sera from both rhesus monkeys (Macaca mulatta) and common marmosets (Callithrix jacchus). The monkeys were at adult age, rhesus monkeys $>4$ years and common marmosets $>1.5$ years, when the experiments were performed. In accordance with the Dutch law on animal experimentation, all study protocols in which these animals took part were reviewed and approved by the Institute's Ethics Committee (Biomedical Primate Research Centre) before the experiments started (application numbers 589, 605, 613/618, 633, 484, 542, 581). The B10.Q/rhd mice originated from Professor Jan Klein, Tübingen, Germany, whereas the BALB/cJ mice originated from Jackson Laboratories (Bar Harbor, ME, USA). The parental inbred strain as well as the B10.Q $\times$ $(\mathrm{BALB} / \mathrm{C} \times \mathrm{B} 10 . \mathrm{Q}) \mathrm{N} 2$ strain were bred in the animal facility of the Institute of Medical Inflammation Research at Lund University, Sweden. The animals were between 8 and 12 weeks old at the start of the experiments. Stockholm norra försöksdjursetiska kommiten, Stockholm, Sweden (permission number N66/10, N169/10) approved the experiments.

\section{Induction and evaluation of $\mathrm{CIA}$ in rhesus monkeys and common marmosets}

Rhesus monkeys were immunized with chicken-derived CII (MD Biosciences, Zürich, Switzerland) and common marmoset monkeys were immunized with either chicken or bovine-derived CII (MD Biosciences), which were dissolved in $0.1 \mathrm{M}$ acetic acid to a final concentration of $10 \mathrm{mg} / \mathrm{ml}$ (for rhesus monkeys) and $5 \mathrm{mg} / \mathrm{ml}$ (for common marmosets) and mixed with an equal volume of complete Freund's adjuvant (Difco, Detroit, MI, USA). CIA was induced by injection of $1 \mathrm{ml}$ (rhesus monkeys) and $0.4 \mathrm{ml}$ emulsion (common marmosets) into the dorsal skin, distributed over 10 spots (rhesus monkeys) and four spots (common marmosets). Clinical signs of arthritis were recorded daily by monitoring of behavioral changes or pain. Twice per week the monkeys underwent a complete physical inspection of all the joints for redness and/or swelling using the integrated discomforted scoring scheme [13]. Late-stage sera were collected from all monkeys and used for CII-specific analysis.

\section{Induction and evaluation of $\mathrm{CIA}$ in mice}

Rat CII was prepared from the SWARM chondrosarcoma by pepsin digestion as described previously $[14,15]$. For induction of chronic arthritis, B10.Q $\times(B A L B / C \times B 10 . Q)$ $\mathrm{N} 2$ mice $(n=10)$ were immunized with $100 \mu \mathrm{g}$ rat CII in $0.1 \mathrm{M}$ acetic acid, emulsified in incomplete Freund's adjuvant (Difco). For induction of acute arthritis, B10.Q mice $(n=10)$ were immunized similarly except for the use of complete Freund's adjuvant (Difco). Both strains were boosted at day 35 with $50 \mu \mathrm{g}$ rat CII in incomplete Freund's adjuvant. Clinical scoring of animals was done blindly up to 80 days for acute arthritis and up to 210 days for chronic arthritis using a macroscopic scoring system: 1 point was given for each swollen or red toe or joint and 5 points for a swollen ankle, adding up to a maximum score of 60 points per mouse. 


\section{Antibody measurements}

\section{Rheumatoid arthritis patients}

The synthesis of human triple-helical CII peptides has been described in detail elsewhere [16]. For antibody measurements, enzyme-linked immunosorbent assay plates (NUNC, Roskilde, Denmark) were coated with human CII peptides $\mathrm{C} 1, \mathrm{U} 1$, and $\mathrm{J} 1(5 \mu \mathrm{g} / \mathrm{ml})$ at $4^{\circ} \mathrm{C}$ overnight. After blocking the plates, paired serum and SF samples (diluted $1: 100$ in radioimmunoassay buffer $+10 \%$ fetal calf serum) were added followed by incubation for 2 hours at room temperature. Horseradish peroxidase-conjugated goat antihuman IgG (Jackson Immuno Research Laboratories, West Grove, PA, USA) was then added, and interaction with bound antibodies was detected using the chromogenic substrate TMB (Sigma-Aldrich St. Louis, MO, USA). Plates were read at $450 \mathrm{~nm}$ with a reference of $650 \mathrm{~nm}$. A standard curve from a positive serum to specific antigen was included on each plate and was further used to translate optical density values to arbitrary units. The cutoff was determined as the mean \pm three standard deviations using the control cohort of 100 healthy individuals. To be able to include all analyzed individuals in the graphs, negative responders were given a value of 0.1 , which is below the detection limit for positivity. The total IgG concentration $(\mathrm{g} / \mathrm{l})$ was determined at the Clinical Immunology Laboratory, Karolinska Hospital, Solna, using commercial radial immune-diffusion assays (Dade-Behring, Marburg, Germany) and rate nephelometry (IMMAGE Immunochemistry System; Beckman Coulter, Fullerton, CA, USA). The assays were calibrated against the international standard CRM470. The paired SF samples were normalized based on the values for total IgG.

\section{Nonhuman primates}

Enzyme-linked immunosorbent assay plates (NUNC) were coated with rat CII $(10 \mu \mathrm{g} / \mathrm{ml})$ and the synthetic CII peptides $\mathrm{C} 1, \mathrm{U} 1$, and $\mathrm{J} 1(5 \mu \mathrm{g} / \mathrm{ml})$ at $4{ }^{\circ} \mathrm{C}$ overnight. After blocking the plates, serum samples (diluted 1:400) from arthritic CIA monkeys were added and incubated for 2 hours in room temperature. Alkaline phosphatase-conjugated goat $(\mathrm{fab})_{2}$ anti-monkey IgG (Invitrogen, Carlsbad, CA, USA) was then added to the bound antibodies, which were detected with polynitrophenylphosphate diluted in Tris buffer (Sigma Aldrich, St. Loius, MO, USA). Absorbance at $405 \mathrm{~nm}$ was measured with a Synergy 2 plate reader (BioTek Instruments). The cutoff value for the assay was calculated as the mean absorbance value of the antibody response to the CII epitopes from naive monkeys \pm three standard deviations (calculated to 0.11). All absorbance values below this cutoff value were considered negative. The serum dilution required for each primate to reach the cutoff absorbance value was calculated. All animals with antibody titers below the detection limit were assigned a value of 1 .

\section{Statistical analysis}

One-way analysis of variance (Kruskal-Wallis test) followed by Dunn's multiple comparison tests were used to analyze the differences between RA and healthy control groups. A paired $t$ test (Wilcoxon signed-rank test) was used for comparison between serum and SF antibody levels. $P<0.05$ was considered statistically significant. Quantitative data are expressed as the mean \pm standard error of the mean, and significance analysis was calculated using the Mann-Whitney test.

\section{Results}

A collagen peptide library generated for systematic epitope mapping of collagen type II

The human CII expression constructs used in this analysis were based on the work of Engel and coworkers $[17,18]$ and the preparation and purification is further explained in Additional file 1. In total, 70 recombinant human CII (rCII) constructs were generated covering the entire triple-helical domain of CII and the N-terminal collagenlike sequence of human CII (Figure 1A). There are several epitopes that have been discovered in CIA in mice and these are marked in Figure 1A. C1, U1, and J1 are the most studied epitopes, and antibodies specific for these epitopes induce arthritis in mice [5-8,19,20]. Following expression and purification, the $\mathrm{rCII}$ peptides were analyzed by sodium dodecyl sulfate polyacrylamide gel electrophoresis, where each peptide band corresponded to the calculated mass of the triple-helical CII peptides $(\sim 25 \mathrm{kDa})$ (Figure 1B). We confirmed that our monoclonal antibodies were conformation dependent; that is, they were restricted to binding the triple-helical CII epitopes in the triple-helical state only, and bound to the rCII peptides containing their specific epitope (Figure 1C). We could also show that antibody binding to the rCII peptides was completely abolished upon heat denaturation of the peptides (Figure 1D).

\section{Identification of several new collagen type II epitopes and epitope spreading in arthritic mice}

To follow the CII-specific antibody response throughout different disease phases we used a mouse strain in which CIA persists chronically, with a relapsing joint inflammation, for over 200 days (Figure 2A) [21]. Arthritis development was monitored and sera were collected at three time points (days 35, 80 and 210). The antibody reactivity of the collected sera to the generated rCII peptide library identified $10 \mathrm{rCII}$ peptides that were frequently recognized, and antibody specificity differed between the different disease phases (Figure 2A,B). Few rCII peptides were recognized at disease onset (Figure 2C), whereas the number of recognized epitopes dramatically increased around early-chronic arthritis (Figure 2D) and slightly decreased in the late-chronic phase (Figure 2E). The rCII 


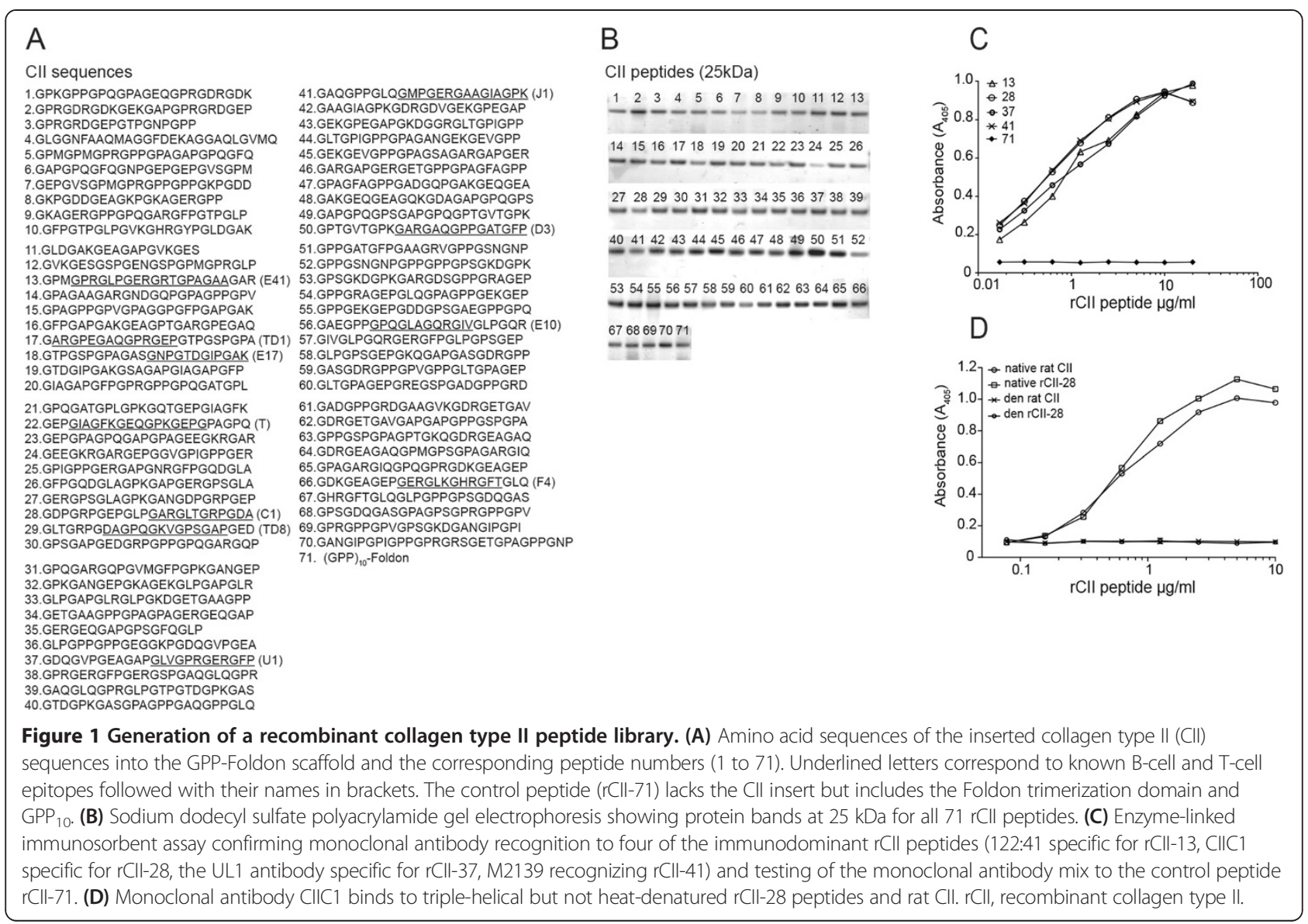

peptides recognized included, among others, the diseaserelated rCII-28, rCII-37, and rCII041, which harbor the major CII epitopes C1, U1, and J1. To investigate the epitope-specific response to that of another arthritis model we followed acute CIA in B10.Q male mice and collected sera at day 50 for CII-specific analysis (Figure 2F). Also here, during the established disease (Figure $2 \mathrm{G}$ ) the major CII epitopes $\mathrm{C} 1, \mathrm{U} 1$, and J1 were prominent together with several other both earlier identified and new CII epitopes.

\section{Antibody responses to $\mathrm{C} 1, \mathrm{U} 1$, and $\mathrm{J} 1$ are prominent in two monkey species with CIA}

To make comparative analyses in nonhuman primates we selected two species, the rhesus macaque ( $M$. mulatta) and the common marmoset (C. jacchus). These developed CIA after immunization with chicken-derived CII [13,22]. The arthritic nonhuman primates had high serum antibody responses towards rat CII, and sera from all 22 rhesus monkeys responded strongly to the major epitopes $\mathrm{C} 1$ and U1 (Figure 3A). Sera from the majority of rhesus monkeys (16 out of 22 samples) showed a high response also towards epitope J1. In contrast, sera from the common marmosets displayed a broader variation in responses against the two major epitopes $\mathrm{C} 1$ and $\mathrm{U} 1$, with more negative samples (Figure 3B). Positive responses to J1 were only detected in three out of the 18 common marmosets.

\section{High frequencies of antibodies to major collagen type II epitopes were observed in RA serum and synovial fluid samples}

For analyzing the response in RA we used a previously described cohort of established RA with both sera and SF from the same patients [11], using an approach where small CII triple-helical peptides of $\mathrm{C} 1, \mathrm{U} 1$, and $\mathrm{J1}$ were synthesized according to a protocol described by Grab and colleagues [23]. We found that the antibody levels against all three CII epitopes were higher in RA patients compared with healthy controls, and the SF patient samples had higher titers than the paired serum samples (Figure 3C,D). In addition, the frequency of patients positive for the $\mathrm{C} 1$ and $\mathrm{U} 1$ epitopes in SF also increased in comparison with sera: $23 \%$ versus $13 \%$ and $77 \%$ versus $47 \%$ for $\mathrm{C} 1$ and $\mathrm{U} 1$, respectively. 


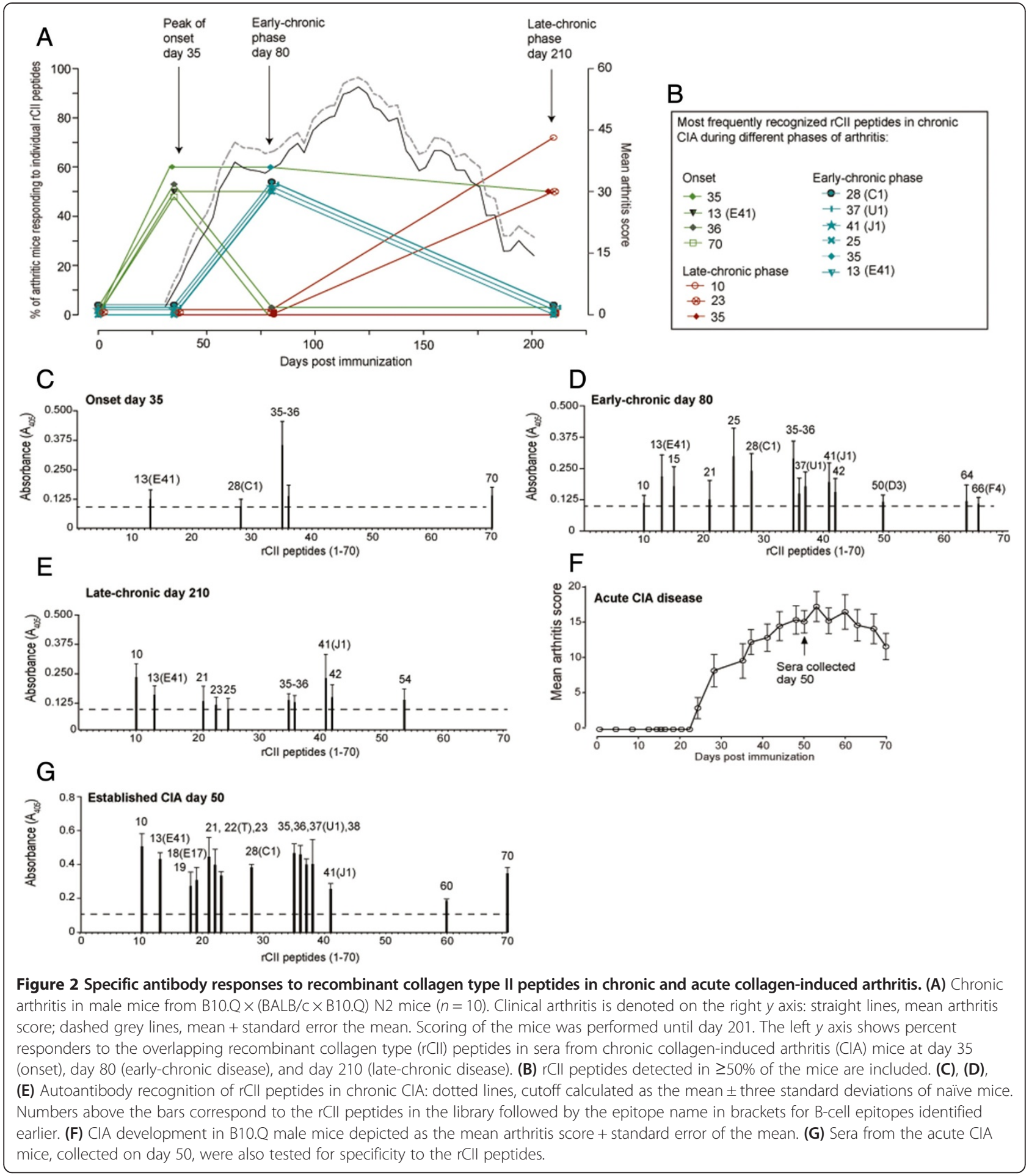

\section{Anti-collagen type II antibody responses differ from the anti-citrullinated protein antibody response}

To investigate whether the anti-CII antibodies define a different subset of RA we used earlier data on the same cohort [11] to correlate with the ACPA response. As summarized in Table 1, all anti-CII antibodies show low $r$ values for correlation with cyclic citrullinated peptide
(CCP), either in serum or SF. In comparison, antibodies against the triple-helical $\mathrm{C} 1$ peptide citrullinated at both arginine positions (that is, CitC1) positively correlate with CCP in serum and SF $(r=0.655$ and $r=0.643$ respectively). Furthermore, in contrast to ACPA that are confined to the CCP-positive RA subset, anti-CII antibodies were found in both the CCP-positive and CCP- 

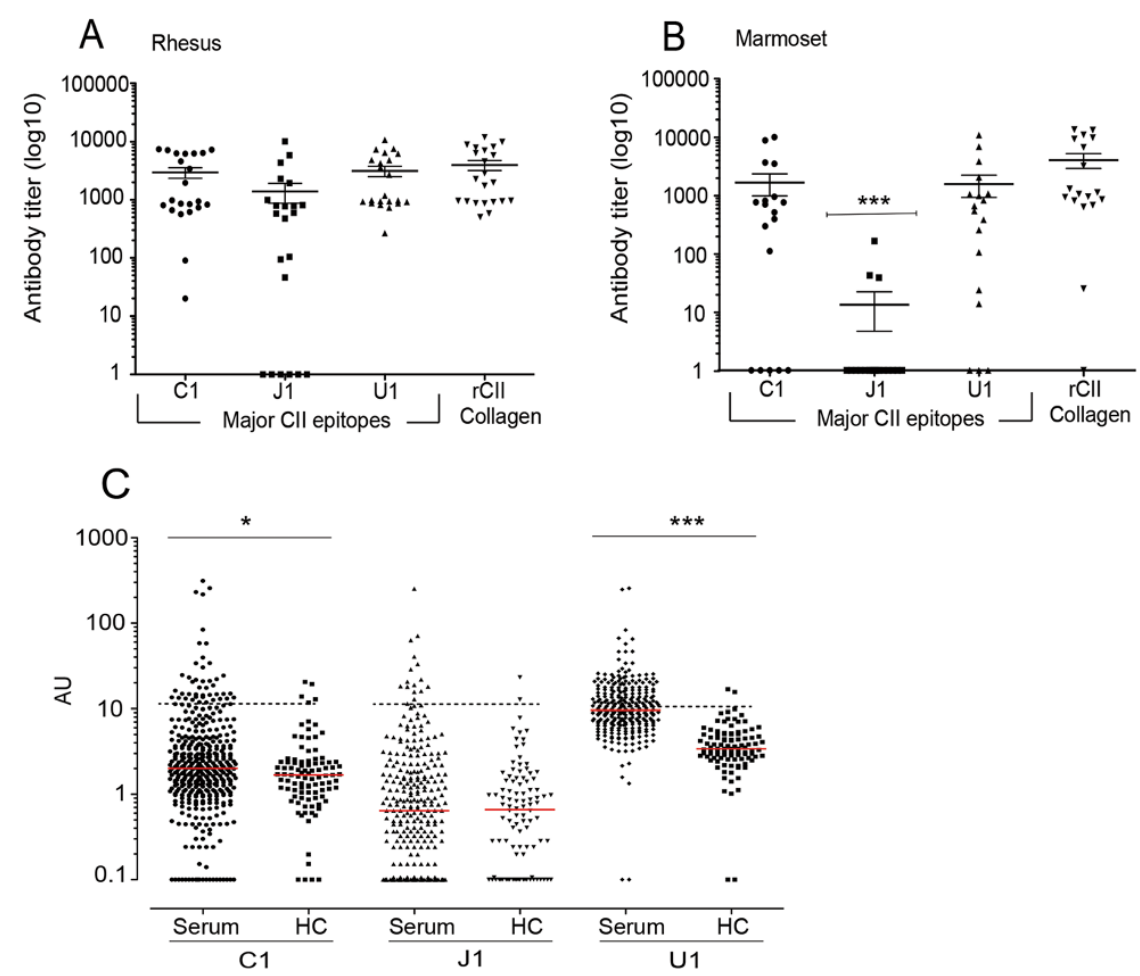

D $\quad$ C1

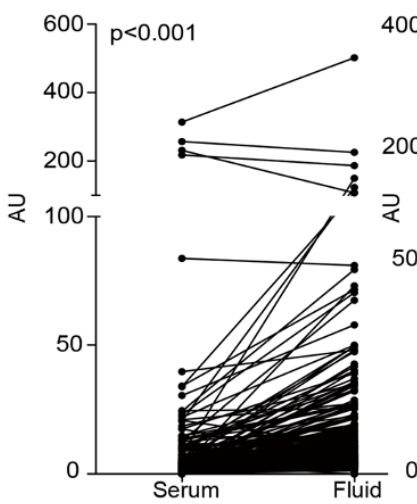

J1

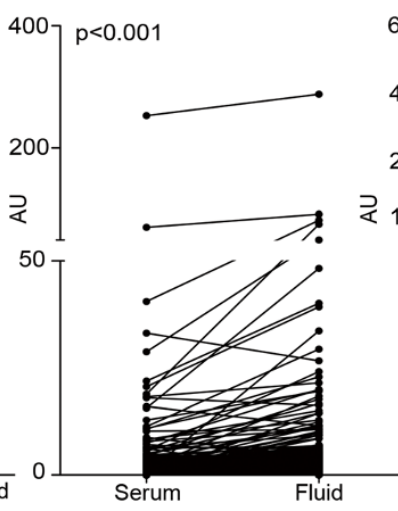

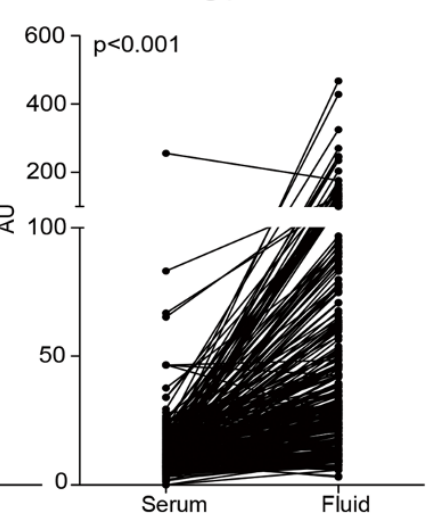

Figure 3 Epitope-specific response in human rheumatoid arthritis and nonhuman primate species. (A), (B) Antibody responses to the major collagen type II (CII) epitopes and to entire triple-helical rat Cll in nonhuman primates (rhesus monkeys and common marmosets). The serum dilution required for each individual to reach the cutoff absorbance value was calculated and is depicted on the $y$ axis. All animals with antibody titers below the detection limit were assigned a value of 1. (C) Antibody responses to major Cll epitopes in sera from rheumatoid arthritis (RA) patients and healthy control $(\mathrm{HC})$ subjects. All individuals with antibody titers below the detection limit for positivity were assigned a value of 0.1. Each data point represents one individual: dotted lines, cutoff value for positivity; horizontal red lines, median. (D) Antibody responses to major Cll epitopes in sera and synovial fluid (SF) from RA patients. After normalization based on the values for total lgG, the levels of anti-C1, anti-U1, and anti-J1 antibodies were determined in paired samples of serum and SF from 290 RA patients. AU, arbitrary units. ${ }^{*} P<0.05,{ }^{* * *} P<0.001$. Values are the mean \pm standard error of the mean.

negative subsets. While only $6 \%$ of CCP-negative patients have anti-CitC1 antibodies in sera, $13 \%$ have antibodies towards $\mathrm{C} 1$ and $38 \%$ towards U1. In SF 5\% of the CCP-negative patients have antibodies against $\mathrm{CitC} 1$, whereas $13 \%$ and $63 \%$ have antibodies against $\mathrm{C} 1$ and $\mathrm{U} 1$, respectively. The distribution of anti-CII antibodies in these two subsets is further illustrated in Figure S1A, $\mathrm{B}$ in Additional file 2.

We further examined whether CII antibodies follow ACPA association with HLA-SE, in particular with HLADRB1*04. We therefore divided our patients into three different groups based on the identity of their SE alleles: 
Table 1 Correlation and frequencies between collagen type II epitopes and CCP

\begin{tabular}{|c|c|c|c|c|c|c|}
\hline \multirow[t]{2}{*}{ Collagen type II epitope } & \multicolumn{2}{|c|}{ Correlation with CCP $(r)$} & \multicolumn{2}{|c|}{ Frequency in sera (\%) } & \multicolumn{2}{|c|}{ Frequency in synovial fluid (\%) } \\
\hline & Serum & Fluid & $\mathrm{CCP}^{-}$ & $\mathrm{CCP}^{+}$ & $\mathrm{CCP}^{-}$ & $\mathrm{CCP}^{+}$ \\
\hline C1 & 0.076 & 0.211 & 12.5 & 12.9 & 13.2 & 27.1 \\
\hline J1 & 0.012 & 0.130 & 8.8 & 5.7 & 7.7 & 5.5 \\
\hline U1 & 0.153 & 0.395 & 37.5 & 50.5 & 62.6 & 82.9 \\
\hline CitC1 & 0.655 & 0.643 & 6.2 & 53.8 & 5.5 & 49.7 \\
\hline
\end{tabular}

CCP, cyclic citrullinated peptide.

those who do not carry the SE alleles $(n=47,-/-)$, patients carrying one or two copies of DRB1*01 alleles $\left(n=50, \mathrm{DR}^{*} 01\right)$, and patients carrying one or two copies of DRB1*04 alleles ( $\left.n=127, \mathrm{DR}^{*} 04\right)$. To better stratify the analysis, patients carrying both the DRB1*01 allele and the DRB1*04 allele $(n=40)$ were excluded from this analysis. In contrast to ACPA levels that strongly associate with HLADRB1*04, the CII examined antibody level association was less pronounced with HLA-DRB1*04 or other SE alleles (Table 2; Figure S2A,B,C,D,E,F in Additional file 3).

\section{Discussion}

In this study we demonstrate that anti-CII antibodies, in particular antibodies directed to the major epitope U1, are frequent and present at the site of inflammation in RA. A significant higher antibody response against the U1 epitope was observed in SF (77\%) compared with levels in sera (47\%), supporting the notion of an increased immune response to locally released CII in the joints. This suggests that anti-CII antibodies appear around the clinical onset and are likely to play a role in the disease process. Antibodies to the investigated three CII epitopes are all shown to be highly arthritogenic in mouse models of RA and one of the first steps observed in the joint pathology is antibody-induced destabilization of cartilage [8]. This observation could open up this tissue for a subsequent inflammatory attack.

We observed a higher prevalence of CII-specific antibodies directed against U1 using our triple-helical peptides compared with previous studies using CII as antigen $[2,4]$. There are several possible explanations for the higher frequency of CII-positive patients when using defined triple-helical peptides as compared with CII isolated from cartilage. Firstly, semi-purified CII derived from tissue is in complex with other matrix proteins, and also with pepsin used for tissue extraction. These contaminants could very probably block potential CII epitopes. Secondly, crosslinking with fibrinogen or denaturation of CII in vitro is likely to disturb assays using semi-purified CII. Thirdly, the smaller triple-helical CII epitopes are coated on enzyme-linked immunosorbent assay plates at higher molar densities than the large CII protein, resulting in capture of antibodies with lower affinity.
Using our assay with defined triple-helical CII epitopes possibly allowed detection of antibodies with lower affinity, and this may have a large effect on the detection rate. Importantly, the anti-CII antibody response in mice, even antibodies that are pathogenic, are to a large extent germline encoded and thereby lack somatic mutated, generated affinity maturation $[6,7,24,25]$. The observed anti-CII antibody response was not confined to the CCP-positive subset of RA and did not significantly associate with specific HLA-DR alleles. The lack of HLA-DR association could, however, be due to low statistical power and because we used a cohort with more established RA, since earlier investigations into early RA have suggested a weak association with DRB1*0401 [26,27].

Despite the genetic differences between rodents, monkeys, and humans and the fact that the experimental arthritis was induced through immunization with CII in the various species leading to strong anti-CII antibody responses, the fine specificity of the major epitopes was still largely conserved. The only exception was the lack of response to the $\mathrm{J} 1$ epitope in the common marmoset. This lack is in fact similar to the mouse in which the response to J1 is strain specific [28]. Interestingly, the heterogeneity in the mouse has been mapped to the variable heavy chain locus, indicating that constraints of the binding structures lead to restrictions in using allele-specific $V$ genes [7]. The analysis of the triple-helical peptide CII library showed that numerous epitopes could be targeted by autoantibodies and responses against different CII epitopes vary at different stages of the disease. The generated CII peptide library revealed that the three more thoroughly investigated major CII epitopes are present in both acute and chronic stages of arthritis. The binding site of a CIIbinding antibody is often the site for binding of matrix proteins (reviewed in [10]), which could explain why the epitope specificity of the antibodies is important for their pathogenicity. CII provides numerous epitopes that are recognized by antibodies in RA but there are also other cartilage protein epitopes to be detected. This leads to the possibility that cartilage is frequently recognized in RA and that these antibodies could play an important role in the disease. Assays to detect such antibodies would therefore provide valuable information, in particular to predict 
Table 2 Odds ratio for the association of antibody-positive patients within the different HLA-DRB1 groups

\begin{tabular}{|c|c|c|c|c|c|c|}
\hline \multirow[b]{2}{*}{ Antigen } & \multirow{2}{*}{$\begin{array}{l}\text { No SE }(n=47) \\
\text { Frequency of } \\
\text { positive patients (\%) }\end{array}$} & \multicolumn{2}{|l|}{ HLA-DRB $1 * 01(n=50)$} & \multicolumn{3}{|l|}{ HLA-DRB1*04 $(n=127)$} \\
\hline & & $\begin{array}{l}\text { Frequency of } \\
\text { positive patients (\%) }\end{array}$ & Odds ratio $\mathrm{DR}^{*} 01$ vs. no SE & $\begin{array}{l}\text { Frequency of } \\
\text { positive patients (\%) }\end{array}$ & Odds ratio $\mathrm{DR}^{*} 04$ vs. no $\mathrm{SE}$ & Odds ratio $\mathrm{DR}^{* 04}$ vs. $\mathrm{DR}^{* 01}$ \\
\hline C1 sera & 14.9 & 16 & $1.088,95 \% \mathrm{Cl} 0.3613$ to 0.280 & 11.8 & $0.7653,95 \%$ Cl0.291 to 2.013 & $0.703,95 \% \mathrm{Cl} 0.278$ to 1.780 \\
\hline C1 SF & 10.6 & 22 & $2.369,95 \% \mathrm{Cl} 0.755$ to 7.436 & 25.2 & $2.829,95 \% \mathrm{Cl} 1.030$ to 7.771 & $1.194,95 \%$ Cl 0.547 to 2.605 \\
\hline J1 sera & 6.4 & 14 & $2.388,95 \% \mathrm{Cl} 0.579$ to 9.845 & 5.5 & $0.856,95 \% \mathrm{Cl} 0.212$ to 3.457 & $0.3583,95 \% \mathrm{Cl} 0.119$ to 1.081 \\
\hline J1 SF & 6.4 & 8 & $1.275,95 \% \mathrm{Cl} 0.361$ to 3.280 & 7.1 & $1.119,95 \% \mathrm{Cl} 0.289$ to 4.324 & $0.469,95 \% \mathrm{Cl} 0.164$ to 1.336 \\
\hline U1 sera & 42.6 & 38 & $0.827,95 \% \mathrm{Cl} 0.367$ to 1.865 & 48 & $1.227,95 \% \mathrm{Cl} 0.624$ to 2.413 & $1.483,95 \% \mathrm{Cl} 0.759$ to 2.898 \\
\hline U1 SF & 68.1 & 82 & $2.135,95 \% \mathrm{Cl} 0.828$ to 5.506 & 76.4 & $1.516,95 \% \mathrm{Cl} 0.7245$ to 3.169 & $0.710,95 \% \mathrm{Cl} 0.310$ to 1.627 \\
\hline CitC1 sera & 27.6 & 26 & $0.919,95 \% \mathrm{Cl} 0.374$ to 2.258 & 53 & $2.921,95 \% \mathrm{Cl} 1.410$ to 6.049 & $3.178,95 \% \mathrm{Cl} 1.544$ to 6.541 \\
\hline CitC1 SF & 17 & 26 & $1.713,95 \%$ Cl 0.637 to 4.606 & 48.8 & $4.650,95 \% \mathrm{Cl} 2.014$ to 10.74 & $2.715,95 \%$ Cl 1.319 to 5.586 \\
\hline
\end{tabular}


and follow the joint inflammatory attack. Further dissection of the CII epitopes, and their citrullinated counterparts $[29,30]$, could be of importance to understand the pathogenic and regulatory pathways in RA.

\section{Conclusions}

Antibody responses against triple-helical CII epitopes are common in RA, and the high antibody titers in SF indicate that these are likely to originate from rheumatoid joints. However, there was no correlation with the ACPA response. Importantly, the fine specificity of the anti-CII response is largely conserved between RA in humans and CIA in monkeys and rodents where the recognized epitopes have a major pathogenic role. In conclusion, our results suggest that anti-CII antibodies are likely to reflect a pathway other than ACPA and may both contribute to, as well as be the consequence of, local joint inflammation.

\section{Additional files}

Additional file 1: is a description of supplementary materials and methods for CII peptide design, expression and purification of recombinant CII peptides, and antibody measurements in mice sera with recombinant $\mathrm{Cll}$ peptides, rhesus monkeys and common marmosets.

Additional file 2: is Figure S1A and S1B showing the distribution of anti-CI antibodies in sera and in synovial fluid of CCP-positive and CCP-negative RA subsets.

Additional file 3: is Figure $S 2 A, B, C, D, E, F$ showing the association between CII antibodies and HLA-SE alleles, in particular HLA-DRB1*04.

The patients were divided into three different groups based on the identity of their SE alleles: those who do not carry the SE alleles ( $n=47,-/-)$, patients carrying one or two copies of DRB1 ${ }^{*} 01$ alleles $\left(n=50, \mathrm{DR}^{*} 01\right)$, and patients carrying one or two copies of DRB1*04 alleles $\left(n=127, \mathrm{DR}^{*} 04\right)$. To better stratify the analysis, patients carrying both the DRB1*01 allele and the $\mathrm{DRB}^{*}{ }^{*} 04$ allele $(n=40)$ were excluded from this analysis. AU, arbitrary units.

\section{Abbreviations}

ACPA: anti-citrullinated protein antibodies; CCP: cyclic citrullinated peptide; CIA: collagen-induced arthritis; Cll: collagen type II; RA: rheumatoid arthritis; rCll: recombinant human collagen type II; SF: synovial fluid.

\section{Competing interest}

$\mathrm{RH}$ is co-inventor of a patent protecting the use of collagen triple-helical epitopes for diagnostic use. The remaining authors declare that they have no competing interests.

\section{Authors' contributions \\ $\mathrm{RH}$ made the conceptual outline of the study. IL, EL and KSN collected and analyzed the rodent data. OS collected and VM analyzed the human data. $\mathrm{MV}$ and $\mathrm{Bt}^{\prime} \mathrm{H}$ collected and IL analyzed the primate data. $\mathrm{HU}$ made the recombinant collagen proteins, and $\mathrm{HU}$ together with IA helped with running assays and the analysis of data. IL wrote the first draft of the manuscript. All authors read, improved and approved the final manuscript. $\mathrm{RH}$ coordinated and supervised the overall study.}

\section{Funding}

This study was supported by The Swedish Research Council, the Swedish Rheumatism Association, the King Gustav V 80-years foundation, the Swedish Science Strategic Foundation (SSF), the KA Wallenberg foundation and the EU projects BeTheCure and Master Switch (HEALTH-F2-2008-223404).

\section{Author details}

${ }^{1}$ Department of Medical Biochemistry and Biophysics, Section for Medical Inflammation Research, Karolinska Institutet, SE-171 77 Stockholm, Sweden. 2Department of Medicine, Rheumatology Unit, Karolinska University Hospital, SE-171 76 Stockholm, Sweden. ${ }^{3}$ Department of Immunobiology, Biomedical Primate Research Centre, $2280 \mathrm{GH}$ Rijswijk, The Netherlands. ${ }^{4}$ Present address; Department of Immunology, Centre for Immune Regulation, Oslo University Hospital-Rikshospitalet, University of Oslo, 0424 Oslo, Norway.

${ }^{5}$ Present address; Department of Molecular Biology and Genetics, Çanakkale Onsekiz Mart Üniversity, 17020 Çanakkale, Turkey.

Received: 5 February 2014 Accepted: 11 June 2014

Published: 8 July 2014

\section{References}

1. Brink M, Hansson M, Mathsson L, Jakobsson P-J, Holmdahl R, Hallmans G, Stenlund H, Rönnelid J, Klareskog L, Dahlqvist SR: Multiplex analyses of antibodies against citrullinated peptides in individuals prior to development of rheumatoid arthritis. Arthritis Rheum 2013, 65:899-910.

2. Holmdahl R, Malmström V, Vuorio E: Autoimmune recognition of cartilage collagens. Ann Med 1993, 25:251-264.

3. Cook AD, Rowley MJ, Mackay IR, Gough A, Emery P: Antibodies to type II collagen in early rheumatoid arthritis. Correlation with disease progression. Arthritis Rheum 1996, 39:1720-1727.

4. Mullazehi M, Wick MC, Klareskog L, van Vollenhoven R, Rönnelid J: Anti-type II collagen antibodies are associated with early radiographic destruction in rheumatoid arthritis. Arthritis Res Ther 2012, 14:R100.

5. Holmdahl R, Rubin K, Klareskog L, Larsson E, Wigzell H: Characterization of the antibody response in mice with type II collagen-induced arthritis, using monoclonal anti-type II collagen antibodies. Arthritis Rheum 1986, 29:400-410.

6. Dobritzsch D, Lindh I, Uysal H, Nandakumar KS, Burkhardt H, Schneider G, Holmdahl R: Crystal structure of an arthritogenic anticollagen immune complex. Arthritis Rheum 2011, 63:3740-3748.

7. Raposo B, Dobritzsch D, Ge C, Ekman D, Xu B, Lindh I, Förster M, Uysal H, Nandakumar KS, Schneider G, Holmdahl R: Epitope-specific antibody response is controlled by immunoglobulin $\mathrm{V}(\mathrm{H})$ polymorphisms. J Exp Med 2014, 211:405-411.

8. Nandakumar KS, Bajtner E, Hill L, Böhm B, Rowley MJ, Burkhardt H, Holmdahl R: Arthritogenic antibodies specific for a major type II collagen triple-helical epitope bind and destabilize cartilage independent of inflammation. Arthritis Rheum 2008, 58:184-196.

9. Holmdahl R, Mo JA, Jonsson R, Karlstrom K, Scheynius A: Multiple epitopes on cartilage type II collagen are accessible for antibody binding in vivo. Autoimmunity 1991, 10:27-34

10. Rowley MJ, Nandakumar KS, Holmdahl R: The role of collagen antibodies in mediating arthritis. Mod Rheumatol 2008, 18:429-441.

11. Snir O, Widhe M, Hermansson M, Spee Von C, Lindberg J, Hensen S, Lundberg K, Engström A, Venables PJW, Toes REM, Holmdahl R, Klareskog L, Malmström $\checkmark$ : Antibodies to several citrullinated antigens are enriched in the joints of rheumatoid arthritis patients. Arthritis Rheum 2010, 62:44-52.

12. Arnett FC, Edworthy SM, Bloch DA, McShane DJ, Fries JF, Cooper NS, Healey LA, Kaplan SR, Liang MH, Luthra HS: The American Rheumatism Association 1987 revised criteria for the classification of rheumatoid arthritis. Arthritis Rheum 1988, 31:315-324.

13. Vierboom MPM, Breedveld E, Kondova I, 't Hart T: Collagen-induced arthritis in common marmosets: a new nonhuman primate model for chronic arthritis. Arthritis Res Ther 2010, 12:R200.

14. Miller EJ, Rhodes RK: Preparation and characterization of the different types of collagen. Meth Enzymol 1982, 82:33-64.

15. Smith BD, Martin GR, Miller EJ, Dorfman A, Swarm R: Nature of the collagen synthesized by a transplanted chondrosarcoma. Arch Biochem Biophys 1975, 166:181-186.

16. Fields GB: Synthesis and biological applications of collagen-model triple-helical peptides. Org Biomol Chem 2010, 8:1237-1258.

17. Frank S, Kammerer RA, Mechling D, Schulthess T, Landwehr R, Bann J, Guo Y, Lustig A, Bächinger HP, Engel J: Stabilization of short collagen-like triple helices by protein engineering. J Mol Biol 2001, 308:1081-1089.

18. Stetefeld J, Frank S, Jenny M, Schulthess T, Kammerer RA, Boudko S, Landwehr R, Okuyama K, Engel J: Collagen stabilization at atomic level: crystal structure of designed (GlyProPro)10foldon. Structure 2003, 11:339-346. 
19. Mo JA, Holmdahl R: The B cell response to autologous type II collagen: biased $\mathrm{V}$ gene repertoire with $\mathrm{V}$ gene sharing and epitope shift. J Immunol 1996, 157:2440-2448.

20. Wernhoff $P$, Unger C, Bajtner E, Burkhardt H, Holmdahl R: Identification of conformation-dependent epitopes and $\mathrm{V}$ gene selection in the $\mathrm{B}$ cell response to type II collagen in the DA rat. Int Immunol 2001, 13:909-919.

21. Nandakumar KS, Lindqvist A-KB, Holmdahl R: A dominant suppressive MHC class II haplotype interacting with autosomal genes controls autoantibody production and chronicity of arthritis. Ann Rheum Dis 2011, 70:1664-1670.

22. Yoo TJ, Kim SY, Stuart JM, Floyd RA, Olson GA, Cremer MA, Kang AH: Induction of arthritis in monkeys by immunization with type II collagen. J Exp Med 1988, 168:777-782.

23. Grab B, Miles AJ, Furcht LT, Fields GB: Promotion of fibroblast adhesion by triple-helical peptide models of type I collagen-derived sequences. J Biol Chem 1996, 271:12234-12240.

24. Mo JA, Scheynius A, Nilsson S, Holmdahl R: Germline-encoded lgG antibodies bind mouse cartilage in vivo: epitope- and idiotype-specific binding and inhibition. Scand J Immunol 1994, 39:122-130.

25. Cao D, Khmaladze I, Jia H, Bajtner E, Nandakumar KS, Blom T, Mo JA, Holmdahl R: Pathogenic autoreactive B cells are not negatively selected toward matrix protein collagen II. J Immunol 2011, 187:4451-4458.

26. Burkhardt H, Hüffmeier U, Spriewald B, Böhm B, Rau R, Kallert S, Engström A, Holmdahl R, Reis A: Association between protein tyrosine phosphatase 22 variant R620W in conjunction with the HLA-DRB1 shared epitope and humoral autoimmunity to an immunodominant epitope of cartilage-specific type II collagen in early rheumatoid arthritis. Arthritis Rheum 2006, 54:82-89.

27. Cook AD, Stockman A, Brand CA, Tait BD, Mackay IR, Muirden KD, Bernard CC, Rowley MJ: Antibodies to type II collagen and HLA disease susceptibility markers in rheumatoid arthritis. Arthritis Rheum 1999, 42:2569-2576.

28. Förster M, Raposo B, Ekman D, Klaczkowska D, Popovic M, Nandakumar KS, Lindvall T, Hultqvist $M$, Teneva I, Johannesson $M$, Ahlqvist $E$, Holmdahl R: Genetic control of antibody production during collagen-induced arthritis development in heterogeneous stock mice. Arthritis Rheum 2012, 64:3594-3603.

29. Uysal H, Bockermann R, Nandakumar KS, Sehnert B, Bajtner E, Engström A, Serre G, Burkhardt H, Thunnissen MMGM, Holmdahl R: Structure and pathogenicity of antibodies specific for citrullinated collagen type II in experimental arthritis. J Exp Med 2009, 206:449-462.

30. Haag S, Schneider N, Mason DE, Tuncel J, Andersson IE, Peters EC, Burkhardt H, Holmdahl R: Mass spectrometric analysis of citrullinated type II collagen reveals new citrulline-specific autoantibodies, which bind to human arthritic cartilage. Arthritis Rheumatol 2014, 66:1440-1449.

\section{doi:10.1186/ar4605}

Cite this article as: Lindh et al.: Type II collagen antibody response is enriched in the synovial fluid of rheumatoid joints and directed to the same major epitopes as in collagen induced arthritis in primates and mice. Arthritis Research \& Therapy 2014 16:R143.

\section{Submit your next manuscript to BioMed Central and take full advantage of:}

- Convenient online submission

- Thorough peer review

- No space constraints or color figure charges

- Immediate publication on acceptance

- Inclusion in PubMed, CAS, Scopus and Google Scholar

- Research which is freely available for redistribution

Submit your manuscript at www.biomedcentral.com/submit
C Biomed Central 